\title{
"Only in Canada? Pity." The Sad Fate of Educational Conservatism in Canada
}

\section{Campbell A. Ross}

\section{THE ARGUMENT}

Some foreign commentators presume that Canadian afairs are simply a pale version of developments in the United States. Roy Lowe recently fell into this error. ${ }^{1}$ He described four distinct though overlapping elements as making up a shared New Right ideology in the United Kingdom, the United States, Australia, and Canada: the appeal to market forces, the determination of central government to exercise system control in curriculum and funding, the appeal to a particular sense of nationhood, and the demand that education serve as an economic stimulant through promotion of skills in new technologies. The weight of evidence came from the first three jurisdictions, most especially the United Kingdom and the United States, but the argument claimed that all four elements were universal. This relatively untested assumption led lowe into obscuring and distorting a unique feature of modern educational conservatism in Canada. In fact, using Lowe's construct of New Right ideology and education in the Englishspeaking world, the Canadian version walks on three legs, not four. In Canada, the New Right has placed little emphasis on promoting a sense of nationhood that is tied to or derived from its past.

The absence in English-speaking Canada of the forms of historicalmindechess found in New Right education ideology elsewhere in the world hints at a significant development in Canadian conservative educational thought. This simplification of educational conservatism resulted from fundamental changes in Canadian political conservatism. George Grant forecast this impending transformation thirty years ago.

The impossibility of conservatism in our epoch is seen in the fact that those who adont that title can be no more than the defenders of whatever structure of power is at any moment necessary to technological change. They provide the external force necessary if the society is to be kept together. They are not conservatives in the sense of being the custodians of something that is not subject to change. ${ }^{2}$

The sheer pervasiveness of marketplace conservatism in the 1990s has obscured and marginalized that traditional form of conservatism whose loss was at the heart of Grant's jeremiad. Traditional conservatism began to crumble in Canada in the 1960 s at such a breathtaking pace that the term "catastrophe" does not seem of out of place. This paper sketches that tradition during 
Canada's first century, analyzes its collapse in post-war Canada, and assesses its present condition and prospects in the 1990s.

To begin, Canadians in the first half of the twentieth century moved away from the country's older Britannic associations. An older, Tory view of the purposes of schooling, based upon a concept of Canada as British North America, became increasingly marginalized after World War II. This erosion accelerated very rapidly in the 1960 s when the older view lost its Canadian political base. That erosion was symbolized by the political collapse of John Diefenbaker's political fortunes following the abrupt withdrawal of support by Canadian business and mercantile interests. For a century those interests had been embodied by Sir John A. Macdonald's National Policy of economic protectionism and imperial connections. Now Canadian businessmen embraced North American continentalism as a better security for their sales and investments and rejected Diefenbaker's anti-Americanism. In the past, these same businesspeople had seen a match between the pattern of their trading and investment activities within the British Empire on the one hand, and the emphasis upon British and European political and literary accomplishments on the other. Now that linkage was gone.

This circumstance helps to explain why the traditional conservative faith in having a sense of the national past has failed to revive in Canada during the last two decades, in contrast to American educational debate. In the United States powerful elements in the Republican Party have championed a definition of "cultural literacy" with a Eurocentric view of national experience. By contrast, this traditional feature of Canadian educational conservatism has been forced into a kind of wilderness as Canada's two major national parties have adopted wholly new outlooks on the matter of national identity. A key element of traditional Canadian conservatism is thus deprived in the 1990s of political energy.

\section{THE HISTORY}

Traditional educational conservatism in Canada acquired its initial energies from the decision to found a North American state different from the insurgent Thirteen Colonies. Canadians sought to establish themselves separately, not wishing to break from the British Crown and distrusting the sweeping Enlightenment principles upon which the American republic was founded. Canadians valued the organic community of the British polity and were reluctant to put at risk the standards of belief and behaviour they derived from that connection. ${ }^{3}$ A half-century after the American Revolution, and with some further small rebellions, Canadians worked their way toward arrangements for 
wider franchise and "responsible government" in the British North America Act of 1867.

Canadian political values, however, remained conservative. A clause of the British North America Act made the primary responsibility of our central authority in Ottawa to be "peace, order and good government," thus adopting a tone in sharp contrast with the preamble of the Constitution of the United States. ${ }^{4}$ In contrast to the United States, founded in the Enlightenment universalist principles of eighteenth-century liberalism, Canada was marked by the high tide of the Victorian political outlook, with its emphasis on upon organic ties, an emphasis increased by the presence of the French-Canadian community. ${ }^{s}$

What most systematically contributed to a sense of community was Hegelian rational idealism. The distinctive role of philosophic idealism in the intellectual history and ethos of Canada has become clear in historical studies over the last fifteen years. Human reason, it asserted, brought non-experiential concepts to bear upon empirical and especially historical evidence to infuse it with meaning. Reason also operated in the realm of morals by enabling humankind to find, in light of its intellectual powers, the values and moral feelings that constituted ideal duty. Two circumstances made these ideas influential in turn-of-the-century Canada. The first was the arrival from Scotland of John Watson as professor of theology at Queen's University in 1872. The second was the relationship between idealist philosophy and those Canadians determined to give the British imperial idea certain moral and cultural qualities.

John Watson's fusion of Kantian and Christian idealism suited the sense of mission of intellectual and cultural leaders in late nineteenth-century Canadian society. Key elements in Watson's intellectual synthesis can be drawn from a non-technical commemorative piece Watson wrote for Queen's Quarterly on the occasion of the death of his own mentor, Edward Caird, one of the leading Scottish idealist philosophers of the age. Watson gave a delightful and vivid account of how Caird's philosophic idealism had shown Watson that the broader reaches of experience operated on the same moral and intellectual constructs as his private thinking.

All this was nothing less than the diselosure of a new world to a Scottish youth, who from his early years had been accustomed to roll like a sweet morsel under his tongue such abstract themes as the relations of faith and works, predestination and foreknowledge. . . The close shell of traditional Calvinism was burst, and we gradually learned to seek for truth in the interpretation of experience, conceived in the widest way as the experience of the race, and as comprehending the vast, slow, never hasting, never resting, movement of humanity. ${ }^{6}$ 
Here we find the central conservative idea which was to infuse the system of public education established in Canada: that human reason could generate the values and standards by which life should be lived and citizenship fulfilled, on the condition that it looked for illustration and confirmation of these in the record of man's experience in the history and culture of the community.

This was the basis of the social conservatism Alison Prentice saw as infusing the educational views of Egerton Ryerson. It was, she said, anxiety in the face of human weakness, along with belief in the elevating power of appropriate school studies, that provided an essential dynamic of mid-nineteenthcentury educational reform. The movement to send all children to school was, above all, a movement to bring "sanctity and order to human affairs.""

Ryerson believed all men possessed a tripartite nature, physical, moral, and intellectual. If the moral and intellectual faculties were undeveloped, a man would be left a mere "material being-a mere mass of bones and sinews, and bodily appetites and passions." "The system of public education which Ryerson constructed on the basis of these beliefs was to be "Christian, universal, free, and compulsory." To impart these values Ryerson selected the Irish National Series of school readers, whose historical and literary selections guided pupils across nineteenth-century Canada. ${ }^{9}$

The 1896 North West Territories curriculum guide stated that pupils were to be led to cherish ideal behaviour through exposure to selected historical events and literature. ${ }^{10}$ As late as 1924 the program of studies for elementary schoolchildren in Alberta stressed that "at this stage they admire especially ideal heroes. It is important that their stories and discussions should most frequently be about admirable people." In Book V at least sixteen stories and eighteen poems described historical or fictional "heroic individuals" and explicitly recommended "cardinal virtues" over "deadly sins," as in the knight Roland exemplifying the virtue of fortitude over the sin of pride. ${ }^{12}$ Approximately twenty-seven selections focused on the British Empire, the character of the British and the "true North strong and free." The sense of national identity subtending the conservative cultural values was dependent on a Canada in the British sphere. A universal moral order was essential to philosophic idealism, and Canadian publicists found its natural basis in what Terry Cook called "the concept of Britannic Idealism." For the educator George Parkin, ". . the Empire was really a state of mind, an ethical concept. . . . He was confident that Anglo-Saxon civilization more than any other reflected the transcendent and organic standards of the Idealist creed which he held so dearly."'3

Philosophic idealism, as a politically significant outlook, eroded during the 1920 s and 1930s. There were a number of causes: the reaction against the horrors of the Great War, the evolution of the British Empire into an 
association of sovereign states, and changes in professional philosophy in Canada. Empiricists such as Adam Shortt rejected metaphysical speculation as a methodology for tackling specific social issues. ${ }^{14}$

Yet Douglas Owram's study of Canadian intellectual life in the interwar period showed that broad idealist notions persisted with surprising strength. "The idealist influence and the religious elements that went with it in Canada, did not disappear overnight - or between generations. . . It remained . . a as a strong current, implicit rather than explicit, shaping the thinking of the generation of the 1930s and 1940s."15 Owram stressed the association of these idealist assumptions with an informal network of "individuals of intellectual outlook, bound together by a number of professional ties, professional relationships and similar attitudes. ${ }^{16}$ Lewis G. Thomas closely described this intellectual community, its key ideas, and its cultural commentary in the interwar and immediate postwar years. It was

a very tight and cosy society, a society where everyone knew each other. Though they did not necessarily like one another they knew how each fitted into the structure... and to whom to go when something had to be done. Otawa was a smal! city; Canada was a country with a small population. The number of people of sufficient means, education and position to give feadership was exceedingly limited and communication between them was, because they could know each other so very well, exceedingly easy."?

One of the best vantage points for identifying and analyzing the change in conservative theories of education in Canada since World War II is the "great debate" about progressive education in Canada in the early 1950s and the active role played in that controversy by a member of the Canadian intellectual elite, Hilda Neatby. Neatby was an historian at the University of Saskatchewan. Lewis G. Thomas had no hesitation in placing Hilda Neatby in that influential minority who had traditionally played an important role in the design of the major institutions that shaped and upheld the distinctive cultural identity of Canada, especially in relation to the United States. ${ }^{18}$ Neatby's sense of cultural difference was sharpened by her role on the postwar Massey Commission on National Development in the Arts, Letters, and Sciences, whose mandate was to carry out the first major analysis of national cultural identity in Canada. Although the report of the Massey Commission in 1951 carefully recognized provincial autonomy in schooling, it was anxious about Canada's increasing reliance on American models of education.

How many Canadians realize that over a large part of Canada the schools are acepting tacit direction from New York that they would not think of accepting from Otlawa? ... our use of American institutions, or our lazy, even abject, imitation of them has caused an uncritical aceeptance of ideas and traditions which are alien to our tradition." 
When Hilda Neatby published So Little for the Mind (1953), a slashing attack on what she saw as anti-intellectual curricula designed by American-trained progressive educators, she articulated the views of a traditional cultural elite. For example, B. K. Sandwell, longtime editor of Canada's literary magazine Saturday Night, described So Little for the Mind as

a thoroughly Canadian book, dealing with Canadian needs and conditions, and making one of its chief charges against Canadian educational progressivism that it is not Canadian, that it is based upon an alien philosophy, invented in and chiefly held by a nation which early in its history cut itself off not only from the political but also from the social and cultural traditions of Europe in a way which Canada has never dreamed of following. ${ }^{20}$

Neatby's book acted as a lightning rod for a whole range of conservative concerns about progressive education. The image around which Neatby developed her commentary was that of "the educated man." Her conservatism was essentially a desire to conserve that particular ideal.

I am disturbed at the apparent indifference of the experts to the disappearance of the oldfashioned concept of the "educated person" who chose to rest his reputation on his bearing and conversation, rather than on degrees and "research." Conversation is, no doubt, one of those rather exclusive recreations indulged in by the aristocracy and unfitted to a stream-lined and community conscious democracy. Yet with all its undeniable merits the new democratic education seems to me to be weakened by inner strains and contradictions. ${ }^{21}$

Throughout So Little for the Mind, Neatby, as spokesperson for the Canadian conservative idealist view in education, explicitly drew its parameters so that it rested almost entirely upon the need to preserve and transmit the history and culture of Western Europe and England in particular. An analysis of public response in major provincial dailies across the country indicates, however, that this crucial aspect of the traditional conservative educational viewpoint was lost on the public, who otherwise supported Neatby's attack on progressive education. ${ }^{22}$ The public was worried about basic academic competence and appropriate behaviour.

Nor did the question of differences between Canadian and American values seem to strike a chord. Although some voices of the 1950s were grounded in philosophic idealism, they were few. From 1957 to 1959 the Royal Commission on Education in Alberta, the Cameron Commission, listened to submissions on the strengths and weaknesses of progressive education in that province. By far the clearest voice challenging the philosophical underpinnings of progressivism came from the spokespersons for the Separate Catholic 
sector. ${ }^{23}$ Yet the Commission failed to reply to their challenge, and the only Catholic member of that commission felt compelled to issue a separate minority report (which suffered the fate of most minority reports).

The traditional injunctions to develop self-control and duty in light of British historical and cultural experience, were by now lost from view. Conservatism had been based upon a belief in the value of organic forms that evolved in one's historical community. Clearly, the material circumstances of "community" were evolving. It was not long before national politics moved away from all previous assumptions of Canada as British North America.

\section{THE TRANSFORMATION}

Somewhere between the end of World War II and the early 1960s a crucial shift took place in the positions of the two major national political parties on the concept of national identity. Whereas the Liberal party had always been attracted by the republicanism of the U.S.A. and open to continentalism in economic policies, the Conservative Party (since 1942, the Progressive Conservative Party) was the party of "the old flag" until after World War II. The transformation of this traditional pattern was symbolized by the collapse of the Conservative government of John Diefenbaker in 1963. Diefenbaker based his policies, especially in defence, foreign investment, and trade, upon the traditional Conservative association with Britain and opposition to the U.S.A. To his chagrin, however, he was attacked and abandoned by the Canadian business and financial class, who had discovered material advantages for themselves in economic continentalism with the United States.

This shift in "conservatism" was the working-out of a dilemma described by George Grant in Technology and Empire (1969)-the competition between a consciously different cultural tradition and the common appetites created by the possibilities of exploiting the natural resources of North America. Canadians "have despised and feared the American for the account of freedom in which their independence was expressed . . . but we are still enfolded with the Americans in the deep sharing of having crossed the ocean and conquered the new land." ${ }^{24}$ This sense of a common commercial destiny was to make the Conservative Party increasingly pro-American after Diefenbaker, especially in its tariff policies, culminating in the North American Free Trade Agreement of 1989.

Meanwhile, the Liberal Party, building on Liberal government initiatives between the world wars and encouraged by the dynamic of party politics, took the place of the Conservatives as the national party. In so doing they reoriented the concept of Canada away from its traditional form as British North America. 
The Liberal Party became the party of an autonomous Canadian nationalism marked by creation of a national flag in 1965 under Pearson, policies of economic nationalism in the 1970 s under Trudeau, and the repatriation of the constitution from Britain in 1982.

The effect was radically to change the political basis for traditional conservative educational views. The Canadian self-concept conventionalized during the Liberal hegemony after 1963 was an historically truncated nationalism. It downplayed Canada's historical ties to Britain and identified the nation with Liberal policies. Among these policies was a commitment to multiculturalism, which subsequently became an important guideline for provincial departments of education. Multiculturalism overlapped much later with the perspective of deconstructionism, which had become an increasingly significant reference point for scholarly work in the humanities, especially history and literature. The effect was to create a kind of double erosion of the relationship of traditional educational conservatism to the dominant historical "sense" of Canada. Provincial departments of education required texts to exemplify standards of multiculturalism and recognition of minorities, and defined these standards in terms of access to power, not necessarily in terms of quotas. This policy raised a dilemma for the traditional conservative concept of the nation, since any definition of a distinct community must by the very defining also be one that delimits. Indeed, the whole enterprise of defining the Canadian historical community was becoming problematic, as became obvious in the difficulties over the "Canada clause" in the debates over the Charlottetown Accord.

The rapid decline in the traditionally strong element of historic-mindedness in Canadian educational conservatism was obscured, as political conservatism itself gained strength in the 1980s and early 1990s. The educational ideas that accompanied this trend emphasized marketplace requirements for participation in a global economy. The Conservative government of Ralph Klein, for example, devised "performance indicators" and introduced Charter schools to promote competition and choice in public schools. Such developments as these exemplified three of the four elements of New Right ideology described by Roy Lowe. Missing was an older conservative idea concerned with conserving a value heritage created by Canadians before the present. It had slipped away so quietly and utterly that few noticed the silence amidst the bombast of "common sense revolution."

\section{ASSESSMENT}

The removal of that perspective weakens what A. B. McKillop regarded as the tension underlying "the moral imperative" of Anglo-Canadian life. McKillop 
viewed Idealism as the conservative Canadian response to national circumstances, equivalent to the Pragmatist movement in the United States as a reflection of national values. It embodied the tension between the active critical role of the free-ranging intellect and importance of maintaining intellectual control and conviction. He believed it was possible to create a genealogy of this moral imperative in Canadian intellectual life: a line of connected conservative thought from John Watson, through the pre-war idealists like Robert Falconer, and into the post-war world with the Massey Commission and such writers as George Grant and Northrop Frye. The moral imperative, he said,

is doubtless a universal aspect of the human condition, for all men draw lessons from experience. What is most distinctive about this phenomenon in Anglo-Canadian thought is that despite its inevitable twists and turns, its different intellectual shapes and emotional shadings, the basic lesson has nevertheless remained constant from generation to generation. . . that it is necessary to reach a modus vivendi between intellectual inquiry and conventional wisdom. ${ }^{25}$

On this view, a balance between intellectual enquiry and the cultural primacy of definitions of how best to live is the highest gift a conservative outlook can contribute to the enterprise of education.

The experience of the traditional conservative view of education in Canada in the last twenty-five years suggests a need to re-examine the adequacy of customary metaphors for the role of conservatism in educational debate. Typical metaphors in histories of educational thought include "swing of the pendulum" or "turn of the tide," and suggest movement that is repetitive only, thus closing our minds to critical changes in conservative thought itself. The very familiarity of these traditional images directs us to an assumption that conservative thought is as it always was. It blinds us to any perception that the former hierarchy of elements in conservatism may have changed dramatically, causing one branch of conservative theory to experience loss while other elements celebrate the victory of the marketplace. Harold Innes was intrigued by the image of the owl Minerva as an explanatory device for changes in cultural values. ${ }^{26}$ The metaphor of Minerva, the ancient symbol for traditional wisdom, attracted the attention of Hegel in his 1824 work The Philosophy of Right and a century later was employed by Karl Mannheim in his classic Ideology and Utopia.

It is only when actuality is mature that the ideal first appears over against the real and that the ideal ... builds it up for itself into the shape of an intellectual realm. When philosophy paints its grey on grey, then has a shape of life grown old. . . The owl of Minerva spreads its wings with the falling of the dusk. ${ }^{27}$ 
The image of Minerva may, then, be a more suitable metaphor for that stage of conservative theorizing which seeks to describe a world outlook whose framework and content are fully described only when they are receding into the past. Hilda Neatby's So Little for the Mind may be an example of this form of conservative theorizing, one that was parallelled in the sense of loss to be found in the writings of George Grant.

I regret the disappearance of indigenous traditions, including my own. It is true that no particularism can adequately incarnate the good. But is it not also true that only through some particular roots, no matter how partal, can humm beings lirst grasp what is good and it is the juice of such roots which for most men sustain their partaking in a more universal good? ${ }^{28}$

Yet, if a sense of a particular community is essential to the acquisition of spiritual and moral values, can the conservative resist legitimizing communities not yet represented in the traditional canon-females, Native Canadians, Inuit, Ukrainian Canadians? If the conservative has argued that the literary and intellectual contents of the Western canon concern the shared experiences of the human condition, then that tradition must demonstrate how conservative insights into the human enterprise are replicated across all cultures and historical particularities. To this point there is little evidence of the emergence of such a synthesis by Canadian writers in the conservative tradition. ${ }^{29}$ The debate over education in Canada is that much the poorer.

\section{NOTES}

1 Roy Lowe, "Further Than Ever Before . . "N New Right Ideology and Education," Historical Studies in Education 7, no. 2 (1995): 177.-91.

2 George Grant, Lament for a Nation (Ottawa: Carleton University Press, 1970), 67.

3 Seymour Lipset, Continenal Divide (New York: Routledge, 1990), 14.

4 Lipset, $43 \cdots 44$.

$5 \quad$ Peter Emberley and Walter Newell, Bankrupt Education: The Decline of Liberal

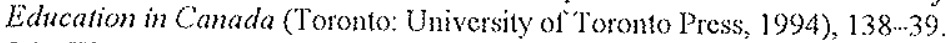

"John Watson, "Edward Caird As Teacher and Thinker," Queen's Quarterly 16 (1909): 303-13.

7. Alison Prentice, The School Promoters (Toronto: McClelland and Stewar1, 1977), 25. 8 Prentice, 28.

" J. D. Wilson, "The Ryerson Years in Canada West," in Education in Canada: An Interpretation, ed. E. Brian Titley and Peter J. Miller (Calgary: Detselig Enterpises, 1982), $61 \ldots 91$.

10 Nancy M. Sheehan, "Indoctrination: Moral Education in the Early Prairie School House," in Shaping the Schools of the Canadian West ed. David C. Jones, Nancy M. Shechan, and Robert M. Stamp (Calgary: Detselig Enterprises, 1979), 222 35. 
N. Tkatch and K. Mazurek, "From IJero to Protagonist: A Comparison of the Moral Content in Two Provincial Reading Series," Alberta English 18, no. 2 (1979): 20-25.

Tkatch and Mazurek.

Terry Cook, "George R. Parkin and the Concept of Britamic Idealism," Joumal of Canadian Studies 10, no. 3 (1975): $15 \cdots 31$.

S. E. D. Short, The Search for an Ideal (Toronto: University of Toronto Press, 1976). Doug Owram, The Government Generation: Canadian Intellectuals and the State 1900-1945 (Toronto: University of Toronto Press, 1986), 331.

Owram, 136.

Lewis G. Thomas, "Associations and Communications," Canadian Historical Association: Historical Papers (1973): 1-12.

Lewis G.Thomas, personal interview, Edmonton, 20 July 1988.

Royal Commission on National Development in the Arts, and Letters and Sciences (Ottawa: King's Printers, 1951), $15 \cdots 16$.

B. K. Sandwell, "Sandwell Here," Financial Post, 3 l October 1953,9.

Hilda Neatby, So Little For the Mind (Toronto: Clarke Irwin and Company Lid., 1953), Preface.

Based upon a survey of editorial and reader opinion for $1953 \ldots 54$ in the following newspapers: Vanconver Province, Edmonton Journal, Regina Leader-Post, Wiminipeg Free Press, Toronto Globe and Mail, Toronto Daily Star, Momtreal Gazette, Halifax Chronicle Herald. Reported in Campbeil A. Ross, "The Neatby Debate and Con" servative Thought in Canada" (Ph.D. diss., University of Alberta, 1989).

Report of the Royal Commission on Lducation in Alberta (Edmonton: Queen's Printer, 1959), Brict 12 , Alberta Catholic School Trustees Association.

George Grant, Techology and Empire (Toronto: House of Anansi, 1969), 17.

A. B. MeKillop, A Disciplined Intelligence (Montral and Kingston: Meoin-Quecii’s University Press, 1979), 231.

Anne Inuss Dagg, "Memories of my Father," Queen's Quarterly 101 (1994): 79.91. Kanl Mannlueim, Ideology and Ulopia (New York: Hareoun, Brace, 1936), 231. Grant, Technology and Empire, $68-69$.

For example, Emberley and Newell, Bankupt Lducation, contains a stimulating review of nineteeth-century models of classic heral education and sfrong eriticism of contemporary curriculum content, but litle reflection on a new synthesis. 